\title{
EVALUASI SISTEM INFORMASI PENGGAJIAN PADA PT XYZ
}

\author{
Hari Setiabudi Husni ${ }^{1}$ : Purwoko $^{2}$; Antonius ${ }^{3}$ \\ 1, 2, 3 Jurusan Komputerisasi Akuntansi, Fakultas Ilmu Komputer, Universitas Bina Nusantara \\ Jln. K.H. Syahdan No. 9, Palmerah, Jakarta Barat 11480 \\ hari.setiabudi@binus.ac.id
}

\begin{abstract}
The purpose of this study was to identify problems and weaknesses in the payroll information system, providing recommendations to reduce the risk of existing problems and produce audit reports for companies. Research method used is through literature study, interviews and observation. Audit method used is the method of auditing around the computer. Analysis was performed by analyzing the findings of problems, risks, and recommendations on the findings of the problem. After doing research, we conclude that there are still some weaknesses in management control and application control. But companies should be more focus on the weaknesses inherent limitations in controlling the application and control the output. Based on these findings, suggested that the company to rectify existing weaknesses and enhance control over payroll information system.
\end{abstract}

Keywords: evaluation of information systems, management control, application control, payroll

\begin{abstract}
ABSTRAK
Tujuan penelitian ini adalah untuk mengidentifikasi masalah dan kelemahan pada sistem informasi penggajian, memberikan rekomendasi untuk mengurangi resiko dari permasalahan yang ada dan menghasilkan laporan audit bagi perusahaan. Metode Penelitian yang digunakan adalah melalui studi pustaka, wawancara serta melakukan observasi. Metode audit yang digunakan adalah metode audit around the computer. Analisis dilakukan dengan menganalisa temuan masalah, resiko, dan rekomendasi atas temuan masalah. Setelah dilakukan penelitian, maka dapat disimpulkan bahwa masih terdapat beberapa kelemahan pada pengendalian manajemen dan pengendalian aplikasi. Tetapi perusahaan harus lebih memfokuskan pada kelemahan-kelemahan yang terdapat dalam pengendalian batasan aplikasi dan pengendalian keluaran. Berdasarkan hasil temuan tersebut, disarankan agar perusahaan melakukan perbaikan terhadap kelemahan-kelemahan yang ada dan meningkatkan pengendalian terhadap sistem informasi penggajian.
\end{abstract}

Kata kunci: evaluasi sistem informasi, pengendalian manajemen, pengendalian aplikasi, penggajian 


\section{PENDAHULUAN}

Dalam memasuki era globalisasi dengan kompetisi bisnis yang semakin ketat dan tajam, maka perusahaan harus berusaha untuk terus meningkatkan kemampuannya agar mampu bertahan dan bersaing dengan para kompetitornya. Sumber Daya Manusia merupakan salah satu elemen organisasi yang berperan penting dalam peningkatan kinerja suatu perusahaan dan Sumber Daya Manusia menjadi pilar penyangga utama sekaligus penggerak roda organisasi dalam usaha tujuan perusahaan. Oleh karena itu Sumber Daya Manusia perlu dikelola secara baik dan profesional agar dapat tercipta keseimbangan antara kebutuhan. Salah satu cara untuk meningkatkan produktivitas tenaga kerja adalah dengan memberikan gaji yang sesuai dan adil kepada setiap karyawan.

Dalam penetapan standar gaji yang memadai dibutuhkan informasi-informasi yang akan berpengaruh terhadap gaji. Dan dengan semakin meningkatnya kebutuhan akan informasi, perusahaan dituntut untuk menyediakan suatu sistem informasi yang dapat mendukung proses penggajian. Oleh karena itu, peneliti memutuskan untuk melakukan evaluasi pada PT XYZ yang bergerak dalam bidang jasa pelayaran kapal laut, dan membawa barang-barang keluar daerah melalui jalan air. Dalam penelitian ini, hal-hal yang akan dibahas antara lain berkaitan dengan pengevaluasian terhadap sistem pengendalian internal yang diterapkan dalam sistem informasi penggajian yang dijalankan oleh perusahaan serta pengevaluasian terhadap laporan yang dihasilkan dan kegiatan pelaporan yang harus dilaporkan secara periodik.

\section{METODE PENELITIAN}

\section{Metode}

Untuk memperoleh data dan informasi dalam penyususan paper ini, metode yang digunakan adalah: metode penelitian kepustakaan, penelitian lapangan (wawancara dan pengamatan/observation), audit, dan analisis data.

\section{Landasan Teori}

\section{Pengertian Sistem Informasi Secara Umum}

Sistem informasi dapat disimpulkan sebagai sekumpulan komponen berupa manusia, perangkat keras, perangkat lunak, jaringan komunikasi dan sumber data yang teroganisasi yang saling berhubungan untuk mengumpulkan data dan memproses data menjadi informasi yang dibutuhkan untuk pengambilan keputusan yang mendukung kegiatan operasional perusahaan.

\section{Pengertian Gaji dan Sistem Penggajian}

Pengertian gaji sendiri dapat disimpulkan bahwa gaji merupakan sejumlah uang yang dibayarkan secara periodik kepada karyawan atas hasil usaha atau jasa yang diberikan karyawan kepada perusahaan. Menurut Mulyadi (2001: 385), sistem penggajian terdiri dari jaringan prosedur seperti prosedur pencatatan waktu hadir, pembuatan daftar gaji, distribusi biaya gaji, pembuatan bukti kas keluar, dan pembayaran gaji. Menurut Mulyadi (2001: 382-384), fungsi yang terkait dalam sistem akuntansi penggajian adalah sebagai berikut. Pertama, fungsi kepegawaian. Fungsi ini bertanggung jawab untuk mencari karyawan baru, menyeleksi calon karyawan, memutuskan penempatan karyawan baru. Kedua, fungsi pencatat waktu. Fungsi ini bertanggung jawab untuk menyelenggarakan catatan waktu hadir bagi semua karyawan perusahaan. Ketiga, fungsi pembuat daftar gaji. Fungsi ini 
bertanggung jawab untuk membuat daftar gaji yang berisi penghasilan bruto yang menjadi hak dan berbagai potongan yang menjadi beban setiap karyawan selama jangka waktu pembayaran gaji. Keempat, fungsi akuntansi. Fungsi akuntansi bertanggungjawab untuk mencatat kewajiban yang timbul dalam hubungannya dengan pembayaran gaji karyawan. Kelima, fungsi keuangan. Fungsi keuangan bertanggungjawab untuk mengisi cek guna pembayaran gaji dan menguangkan cek tersebut ke bank.

Menurut Mulyadi (2001: 374-379), dokumen yang digunakan dalam sistem akuntansi penggajian adalah: dokumen pendukung perubahan gaji, kartu jam hadir, kartu jam kerja, daftar gaji, rekap daftar gaji, surat pernyataan gaji, amplop gaji, dan bukti kas keluar. Sedangkan menurut Mulyadi (2001: 382), catatan akuntasi yang digunakan dalam pencatatan gaji adalah: jurnal umum, kartu harga pokok produk, kartu biaya, dan kartu penghasilan karyawan. Sistem Informasi Penggajian dapat disimpulkan sebagai subsistem atau bagian dari SISDM yang secara khusus mengumpulkan, memelihara dan mengubah data penggajian menjadi suatu informasi serta mendistribusikan informasi tersebut kepada pemakai dalam organisasi.

\section{Pengertian Audit Sistem Informasi dan Tahapannya}

Audit sistem informasi dapat disimpulkan menjadi suatu proses yang meliputi kegiatan pengumpulan dan pengevaluasian data dan informasi yang diperoleh untuk menilai ketaatan sistem komputer terhadap kebijakan dan prosedur pengendalian internal dalam melindungi aset, meningkatkan integritas serta meningkatkan efektivitas dan efisiensi sistem. Menurut Weber (1999: 510), faktor yang mendorong pentingnya kontrol dan audit sistem informasi adalah: biaya perusahaan yang timbul karena kehilangan data (organizational costs of data loss); biaya yang timbul karena kesalahan dalam pengambilan keputusan (costs of incorrect decision making); biaya yang timbul karena penyalahgunaan komputer (costs of computer abuse); nilai dari hardware, software, dan personnel (value of hardware, software, personnel); biaya yang besar akibat kerusakan komputer (high costs of computer error); perlunya melakukan perlindungan terhadap privasi (maintenance of privacy) serta perlunya pengendalian terhadap perubahan penggunaan komputer (controlled evolution of computer use).

Menurut Weber yang telah dikutip oleh Gondodiyoto (2003: 152-153), tujuan audit sistem informasi dapat disimpulkan secara garis besar menjadi empat tahap yang dapat dijabarkan sebagai berikut: pertama, meningkatkan aset-aset perusahaan. Aset informasi suatu perusahaan seperti perangkat keras (hardware), perangkat lunak (software), sumber daya manusia, data (file) harus dijaga oleh suatu sistem pengendalian internal yang baik agar tidak terjadi penyalahgunaan aset perusahaan; kedua, meningkatkan integritas data. Integritas data (data integrity) adalah salah satu konsep dasar sistem informasi; ketiga, meningkatkan efektivitas system. Efektivitas sistem informasi perusahaan memiliki peranan penting dalam proses pengambilan keputusan; dan keempat, meningkatkan efisiensi system. Efisiensi menjadi hal yang sangat penting ketika suatu komputer tidak lagi memiliki kapasitas yang memadai. Menurut Weber (1999: 47-55), tahapan-tahapan audit sistem informasi terdiri dari halhal sebagai brikut. Pertama, perencanaan audit (planning the audit).

Bagi seorang auditor eksternal, hal ini berarti menyelidiki dari awal atau melanjutkan yang ada untuk menentukan apakah perjanjian audit dapat diterima, dan mengusahakan tinjauan prosedur analitis untuk memahami bisnis klien dengan lebih baik dan mengidentifikasi area yang beresiko dalam audit tersebut. Kedua, pengujian atas pengendalian (test of controls). Apabila pengujian menunjukkan hasil yang tidak sesuai dengan yang diharapkan, maka hal tersebut berarti pengendalian manajemen tidak berjalan sebagaimana mestinya. Ketiga, pengujian atas transaksi (test of transaction). Dari suatu perspektif bukti, auditor menggunakan pengujian atas transaksi untuk menilai apakah terdapat kesalahan atau terjadi pemrosesan transaksi tidak beraturan yang telah mendorong suatu pernyataan tidak material atas informasi keuangan. Pengujian atas transaksi meliputi pengecekan ayat jurnal dari dokumen sumber, menguji nilai kekayaan dan ketepatan komputerisasi. Keempat, 
Pengujian atas saldo atau hasil keseluruhan (tests of balances or overall results). Auditor melakukan pengujian atas saldo atau hasil keseluruhan untuk memperoleh bukti yang cukup untuk membuat penilaian akhir pada tingkat kehilangan atau pernyataan keuangan yang salah yang terjadi ketika fungsi sistem informasi gagal aset, memelihara integritas data dan mencapai sistem yang efektif dan efisien. Kelima, penyelesaian atas audit (completion of the audit). Dalam tahap terakhir audit ini, auditor eksternal melakukan beberapa pengujian tambahan untuk mengumpulkan bukti untuk penutup.

\section{Pengertian Sistem Pengendalian Internal Secara Umum}

Pengertian dari sistem pengendalian internal dapat disimpulkan bahwa sistem pengendalian internal merupakan metode atau alat yang dikoordinasikan untuk melindungi aset-aset perusahaan, menjaga keandalan data dan informasi, dan mendorong dipatuhinya kebijakan manajemen agar tidak terjadi kecurangan dan kejahatan komputer.

Menurut Mulyadi (2001: 164-172), unsur pokok sistem pengendalian internal adalah struktur organisasi yang memisahkan tanggung jawab fungsional secara tegas; sistem wewenang dan prosedur pencatatan yang memberikan perlindungan yang cukup terhadap kekayaan, hutang, pendapatan dan biaya; praktik yang sehat dalam melaksanakan tugas dan fungsi setiap unit organisasi; karyawan yang mutunya sesuai dengan tanggungjawabnya yang dapat dijabarkan sebagai berikut: struktur organisasi yang memisahkan tanggung jawab fungsional secara tegas; sistem wewenang dan prosedur pencatatan yang memberikan perlindungan yang cukup terhadap kekayaan, utang, pendapatan, dan biaya; praktik yang sehat dalam melaksanakan tugas dan fungsi setiap unit organisasi serta karyawan yang mutunya sesuai dengan tanggungjawabnya.

Menurut Weber (1999: 67-648), pengendalian internal berbasis komputer terbagi menjadi dua sebagai berikut: Pertama, pengendalian manajemen (manajemen control) adalah sistem pengendalian internal komputer yang berlaku umum meliputi seluruh kegiatan komputerisasi sebuah organisasi secara menyeluruh. Pengendalian manajemen terdiri dari: pengendalian top manajemen (top management controls), pengendalian manajemen pengembangan sistem (system development management controls), pengendalian manajemen program (programming management controls), pengendalian manajemen sumber data (data resources management controls), pengendalian manajemen keamanan (security administration management controls), pengendalian manajemen operasional (operations management controls), dan pengendalian manajemen jaminan kualitas (quality assurance management controls).

Menurut Gondodiyoto (2003: 127-129), terdapat satu penambahan teori pada pengendalian umum, yaitu pertama adalah pengendalian manajemen sistem informasi (information system management controls). Yang berikutnya adalah pengendalian aplikasi (applications controls). Pengendalian khusus atau pengendalian aplikasi (application controls) adalah sistem pengendalian internal komputer yang berkaitan dengan pekerjaan atau kegiatan tertentu yang telah ditentukan (setiap aplikasi berbeda karakteristik dan kebutuhan pengendaliannya). Pengendalian aplikasi terdiri dari: pengendalian batasan sistem aplikasi (boundary controls), yang mengendalikan sifat dan fungsi pengendalian akses, penggunaan pengkodean dalam pengendalian akses, nomor identifikasi personal (PIN), digital signatures dan plastic cards serta pengendalian masukan (input controls).

Menurut Weber (1999: 420-450) komponen pada subsistem masukan bertanggungjawab dalam mengirimkan data dan instruksi ke dalam sistem aplikasi dimana kedua tipe input tersebut haruslah divalidasi, selain itu banyaknya kesalahan yang terdeteksi harus dikontrol sehingga input yang dihasilkan akurat, lengkap, unik, dan tepat waktu, yang terdiri dari: pengendalian proses (process controls). Pengendalian proses dilaksanakan setelah memasuki sistem dan program-program aplikasi mengolah data; pengendalian keluaran (output controls). Menurut Weber (1999: 615), subsistem output menyediakan fungsi yang menentukan isi dari data yang akan didistribusikan kepada user, caracara data dibentuk dan ditampilkan ke user, dan cara-cara data dipersiapkan dan dikirimkan ke user; 
pengendalian database (database controls). Subsistem database berfungsi untuk mendefinisikan, membuat, membaca, mengubah dan menghapus data pada sistem informasi; pengendalian komunikasi (communication controls). Subsistem komunikasi bertanggungjawab untuk mengirim data ke seluruh sistem lainnya dalam suatu sistem dan untuk mengirim data dari sistem lainnya.

\section{HASIL DAN PEMBAHASAN}

Perusahaan atau PT XYZ didirikan pada tahun 1966 dengan maksud dan tujuan mengembangkan usaha di dalam melancarkan distribusi dan akumulasi barang-barang dari pulau Jawa serta ke daerah-daerah pedalaman dan sekitarnya. Sejalan dengan perkembangan dan kemajuan kondisi perusahaan, PT XYZ secara bertahap melakukan evaluasi atas struktur organisasi. Adapun struktur organisasi di PT XYZ merupakan Organisasi Garis (Line Organization), setiap bagian ditangani oleh satu komando yang berwenang melakukan koordinasi kebawah dalam batas-batas fungsinya. Berikut ini adalah struktur organisasi PT XYZ (Gambar 1).

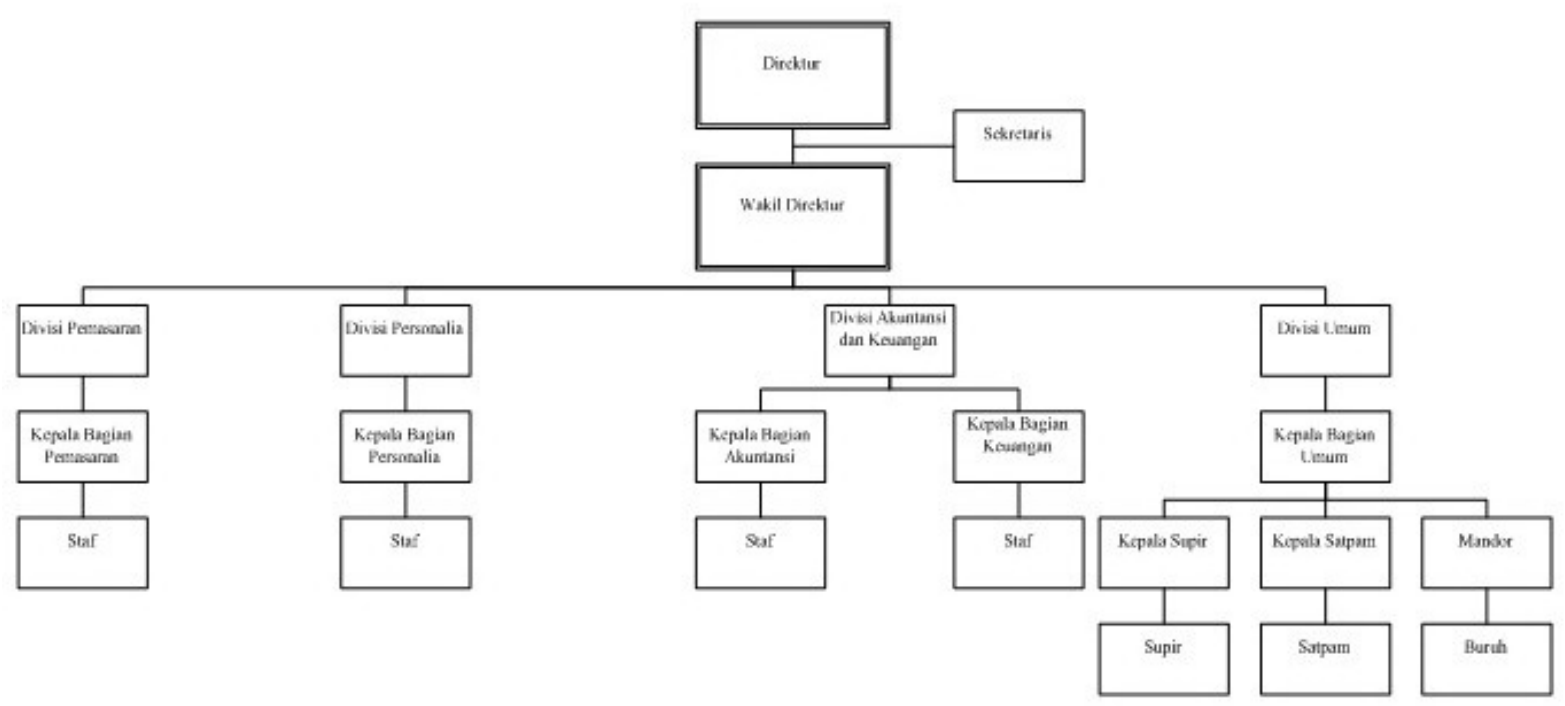

Gambar 1 Struktur Organisasi PT.XYZ

\section{Tugas, Wewenang, dan Tanggung Jawab}

Pertama adalah direktur utama. Direktur utama bertanggung jawab terhadap segala kegiatan yang berhubungan dengan kelangsungan hidup perusahaan. Direktur Utama berwenang dalam menentukan tujuan perusahaan dan dalam menetapkan keputusan yang berhubungan dengan kelangsungan hidup perusahaan. Kedua adalah sekretaris. Tugasnya adalah mengatur dan membuat perjanjian untuk keperluan direktur utama dalam mengadakan rapat (meeting) dengan staf dan para karyawan. Ketiga adalah wakil direktur. Tugasnya adalah mengawasi manajemen yang berada dibawahnya agar sesuai dengan tujuan perusahaan. Keempat adalah kepala bagian pemasaran. Tugasnya adalah mengawasi dan mengkoordinasi kegiatan-kegiatan dalam melaksanakan pemasaran. Kelima adalah staf pemasaran. Tugasnya adalah menjual ruangan kapal yang dimiliki oleh PT XYZ untuk muatan-muatan kepada para pelanggan lama maupun baru. Keenam adalah kepala bagian personalia, yang bertanggung jawab kepada wakil direktur. Tugasnya adalah mengawasi dan mengkoordinasi kegiatan seleksi, perekrutan dan pemberhentian karyawan dan buruh serta menerima laporan hasil seleksi, perekrutan dan pemberhentian karyawan dan buruh. Ketujuh adalah staf 
personalia. Tugasnya adalah membuat laporan hasil seleksi, perekrutan dan pemberhentian karyawan dan buruh serta menghitung gaji berdasarkan daftar hadir karyawan dan buruh. Kedelapan adalah kepala bagian keuangan. Tugasnya adalah mengawasi dan mengkoordinasi kegiatan yang berkaitan dengan keuangan serta memeriksa dan mengotorisasi pengeluaran kas. Kesembilan adalah staf keuangan. Tugasnya adalah bertanggung jawab kepada kepala bagian keuangan serta menyimpan bukti penerimaan dan pengeluaran kas.

Kesepuluh adalah kepala bagian akuntansi. Tugasnya adalah bertanggung jawab kepada wakil direktur serta mengawasi dan mengkoordinasi kegiatan yang berkaitan dengan akuntansi. Kesebelas adalah staf akuntansi. Tugasnya adalah bertanggung jawab kepada kepala bagian akuntansi serta menjurnal dan mencatat setiap transaksi yang dilakukan oleh perusahaan. Keduabelas adalah kepala bagian umum. Tugasnya adalah bertanggung jawab atas keamanan dan kelancaran aktivitas operasional perusahaan sehari-hari serta mengawasi dan mengkoordinasi setiap kegiatan operasional perusahaan secara umum. Ketigabelas adalah kepala supir, yang bertanggung jawab atas pengaturan pemakaian kendaraan. Keempatbelas adalah supir, yang bertugas mengantar jemput ketika diperlukan untuk memperlancar kegiatan operasional perusahaan. Kelimabelas adalah kepala satpam, yang tugasnya bertanggung jawab atas pengaturan jaga dari setiap satpam yang bekerja. Keenambelas adalah satpam, yang tugasnya menjaga kemanan dan ketertiban di daerah lingkungan perusahaan. Ketujuhbelas adalah mandor, yang tugasnya mengatur setiap aktivitas yang harus dilakukan di pelabuhan. Yang terakhir adalah buruh, yang bertugas untuk melakukan packing barang di pelabuhan.

\section{Sistem Informasi yang sedang Berjalan}

\section{Prosedur Penggajian pada Karyawan yang sedang Berjalan}

Pertama, karyawan melakukan absensi dengan mengisi daftar hadir karyawan. Kedua, berdasarkan daftar hadir karyawan, bagian personalia menghitung gaji karyawan per bulan. Ketiga, berdasarkan hasil penghitungan gaji karyawan, bagian personalia menginput dengan aplikasi dan mencetak daftar gaji karyawan sebanyak dua rangkap yang selanjutnya akan diotorisasi oleh kepala bagian personalia. Rangkap satu diarsip oleh bagian personalia dan rangkap dua diserahkan ke bagian keuangan. Keempat, bagian keuangan membuat bukti kas keluar yang akan diotorisasi oleh kepala bagian keuangan. Kemudian bukti kas keluar tersebut akan dijadikan dasar untuk menjurnal dan selanjutnya diarsip oleh bagian keuangan. Kelima, bagian personalia menginput dengan menggunakan aplikasi dan mencetak slip gaji rangkap dua. Rangkap satu diserahkan kepada karyawan dan rangkap dua diarsipkan.

Keenam, bagian personalia memberikan buku penerimaan gaji untuk ditandatangani oleh karyawan, untuk diarsip sebagai bukti perusahaan telah memberikan gaji kepada karyawan. Ketujuh, jika karyawan ingin meminjam uang, maka karyawan memberitahukan ke bagian personalia. Besarnya sesuai dengan kebijakan yang berlaku di perusahaan yang disepakati oleh perusahaan dan karyawan. Kedelapan. selanjutnya bagian personalia membuat surat permohonan yang akan ditandatangani oleh karyawan dan diotorisasi oleh kepala bagian personalia. Kesembilan, kemudian berdasarkan surat permohonan terotorisasi, bagian keuangan membuat bukti kas keluar untuk diotorisasi kepala bagian keuangan. Kesepuluh, selanjutnya bagian keuangan menyerahkan uang pinjaman ke kepala bagian personalia untuk diserahkan ke karyawan. Kesebelas, sedangkan cara pembayarannya adalah dengan sesuai kebijakan yang berlaku di perusahaan yang disepakati oleh perusahaan dan karyawan.

\section{Prosedur Pengupahan}

Pertama, mandor mengisi daftar hadir mandor dan buruh. Kedua, mandor menyerahkan daftar hadir mandor dan buruh kepada bagian personalia. Ketiga, berdasarkan daftar hadir mandor dan buruh, bagian personalia menghitung upah mandor dan buruh. Keempat, berdasarkan hasil penghitungan 
upah buruh, bagian personalia menginput dengan menggunakan aplikasi dan mencetak sebanyak dua rangkap yang selanjutnya akan diotorisasi oleh kepala bagian personalia. Rangkap satu diarsip oleh bagian personalia dan rangkap dua diserahkan ke bagian keuangan. Kelima, bagian keuangan membuat bukti kas keluar yang akan diotorisasi oleh kepala bagian keuangan, kemudian bukti kas keluar tersebut dijadikan dasar untuk menjurnal dan selanjutnya diarsip oleh bagian keuangan. Keenam, bagian keuangan menyerahkan sejumlah uang kepada kepala bagian personalia.

Ketujuh, bagian personalia membuat kwitansi untuk pembayaran upah setiap mandor dan buruh. Kedelapan, kepala bagian personalia membayar upah kepada para mandor dan buruh serta menyerahkan kwitansinya. Kesembilan, jika buruh ingin meminjam uang, maka karyawan memberitahukan ke bagian personalia. Besarnya sesuai dengan kebijakan yang berlaku di perusahaan yang disepakati oleh perusahaan dengan mandor dan buruh. Kesepuluh, selanjutnya bagian personalia membuat surat permohonan yang akan ditandatangani oleh karyawan dan diotorisasi oleh kepala bagian personalia. Kesebelas, kemudian berdasarkan surat permohonan terotorisasi, bagian keuangan membuat bukti kas keluar untuk diotorisasi kepala bagian keuangan. Keduabelas, selanjutnya bagian keuangan menyerahkan uang pinjaman ke kepala bagian personalia untuk diserahkan ke mandor dan buruh. Ketigabelas, cara pembayarannya adalah dengan sesuai kebijakan yang berlaku di perusahaan yang disepakati oleh perusahaan dengan mandor dan buruh.

\section{Evaluasi Sistem Informasi Penggajian}

\section{Hasil Audit}

Berdasarkan pemeriksaan dan pengamatan yang dilakukan, kami selaku tim auditor memberikan laporan hasil audit sebagai berikut. Pertama adalah pengendalian manajemen keamanan. Terdapat beberapa kelemahan pada pengendalian manajemen keamanan antara lain, yaitu perusahaan belum melengkapi komputer dengan firewall untuk menjaga kemanan datanya sehingga tingkat keamanan lebih rendah dan adanya kemungkinan hacker mengakses data; perusahaan tidak memiliki alarm kebakaran otomatis dan tidak memasang alat pemadam kebakaran otomatis maupun manual untuk mengantisipasi terjadinya kebakaran sehingga dapat menyebabkan kebakaran yang lebih besar dan kemungkinan korban jiwa yang semakin banyak; ruangan tempat penyimpanan data dan sistem informasi terletak pada ruangan yang tidak aman dari ancaman banjir sehingga apabila terjadi bencana banjir, dapat menyebabkan data rusak dan hilang terlebih jika terjadi kerusakan pada komputer dan menambah pengeluaran biaya pergantian komputer yang cenderung tinggi.

Dari hasil temuan tersebut, maka auditor menyarankan perusahaan melengkapi komputer dengan firewall; menyediakan alarm kebakaran otomatis dan alat pemadam kebakaran otomatis maupun manual; sebaiknya ruangan penyimpanan data dan sistem informasi diletakkan pada tempat yang aman dari ancaman banjir seperti di ruangan yang lebih tinggi.

Kedua adalah pengendalian manajemen operasional. Pengendalian manajemen operasional masih memiliki beberapa kelemahan seperti tidak terdapatnya kamera pengawas di lingkungan perusahaan sehingga keamanan perusahaan belum sepenuhnya terkontrol dengan baik dan adanya kemungkinan ancaman datang dari dalam perusahaan; tidak terdapat pengawasan terhadap fasilitas kantor sehingga karyawan dapat menggunakan fasilitas kantor untuk kepentingan diri sendiri yang mengakibatkan biaya tambahan yang merugikan perusahaan serta pengawasan yang dilakukan terhadap absensi karyawan masih belum optimal karena terdapat kejadian dimana karyawan dapat mengabsen kehadiran temannya sehingga menimbulkan pelanggaran terhadap jam kerja dan mempengaruhi kinerja karyawan.

Dari hasil temuan diatas, maka auditor menyarankan pengamanan terhadap lingkungan perusahaan tidak hanya menggunakan satpam tetapi juga memasang kamera pengawas pada ruangan- 
ruangan yang menyimpan aset berharga; membuat kebijakan mengenai penggunaan fasilitas kantor dan memberikan sanksi yang tegas bagi karyawan yang melakukan pelanggaran serta terdapat Staf Bagian Personalia yang mengawasi jalannya pengisian absensi pada saat jam masuk dan keluar kantor.

Ketiga, pengendalian batasan sistem aplikasi. Pengendalian batasan sistem aplikasi memiliki beberapa kelemahan sebagai berikut: tidak terdapat ketentuan panjang minimal password; pergantian password tidak pernah dilakukan sehingga tingkat keamanan terhadap akses yang tidak terotorisasi lebih rendah; perusahaan tidak melakukan sistem enkripsi terhadap password user sehingga password lebih mudah dipecahkan oleh hacker; setiap akses dilakukan terhadap sistem tidak direkam sehingga sulit melakukan audit trail; tidak terdapat batasan maksimum untuk kesalahan pengisian password serta aplikasi tidak menghitung jumlah kehadiran karyawan sehingga kehadiran penghitungan jumlah kehadiran karyawan dihitung secara manual lalu baru diinput ke dalam aplikasi. Dari hasil temuan diatas, maka auditor menyarankan perusahaan membatasi panjang minimal password yang jelas sehingga adanya kontrol terhadap penggunaan password dibawah standard; password diganti sesering mungkin sesuai kebutuhan user dan perusahaan; password dienkripsi dengan menggunakan teknik substituion chippers; menggunakan alat perekam otomatis seperti key logger untuk memudahkan proses audit trail; memberikan kesempatan untuk memasukkan password tiga kali serta sistem dilengkapi dengan aplikasi yang dapat melakukan penghitungan jumlah kehadiran karyawan.

Keempat, pengendalian masukan. Dalam pengendalian masukan masih terdapat kelemahankelemahan seperti dokumen yang diinput tidak menggunakan nomor urut tercetak sehingga dokumen tidak terkontrol dengan baik dan sulit mendeteksi dokumen yang hilang; tidak membuat berita acara untuk penghancuran dokumen sehingga tidak mengetahui dokumen apa saja yang dihancurkan dan kapan proses tersebut dilakukan; tidak menggunakan alat penghancur kertas saat proses penghancuran dokumen sehingga dokumen yang tidak hancur secara total dapat disalahkan oleh orang lain serta sistem penggajian tidak dilengkapi dengan help facility sehingga memerlukan waktu yang lebih lama untuk mempelajari sistem; apabila terjadi kesalahan dalam penginputan data, aplikasi tidak menampilkan error message.

Kelima, pengendalian keluaran. Kelemahan-kelemahan yang terdapat pada pengendalian keluaran antara lain: tidak tersedia kolom tanda tangan dan nama pembuat laporan sebagai bukti tanggung jawab atas laporan yang dihasilkan; tidak menggunakan berita acara untuk menghancurkan laporan-laporan yang tidak diperlukan lagi sehingga tidak mengetahui laporan apa saja yang telah dihancurkan dan kapan proses tersebut dilakukan; perusahaan tidak menggunakan alat penghancur kertas ketika melakukan proses penghancuran laporan dan laporan yang tidak hancur secara total dapat disalahgunakan orang lain. Dari hasil temuan tersebut, maka auditor menyarankan setiap laporan harus disediakan kolom tanda tangan dan nama pembuat laporan; membuat berita acara untuk penghancuran kertas sehingga proses penghancuran lebih efektif dan aman.

\section{SIMPULAN}

Berdasarkan hasil pemeriksaan dan pengamatan yang dilakukan dapat disimpulkan bahwa: pertama, mengenai pengendalian manajemen keamanan. Terdapat beberapa kelemahan pada pengendalian manajemen keamanan, yaitu di mana perusahaan belum melengkapi komputer dengan firewall; perusahaan tidak memasang alarm kebakaran otomatis maupun manual dan alat pemadam kebakaran untuk menanggulangi bahaya kebakaran; ruangan tempat penyimpanan data dan sistem informasi terletak pada ruangan yang tidak aman dari ancaman banjir. Kedua, mengenai pengendalian manajemen operasional. Pengendalian manajemen operasional memiliki beberapa kelemahan seperti tidak terdapatnya kamera pengawas di lingkungan perusahaan sehingga keamanan perusahaan belum sepenuhnya terkontrol dengan baik; tidak terdapat pengawasan terhadap fasilitas kantor sehingga 
karyawan dapat menggunakan fasilitas kantor untuk kepentingan diri sendiri serta pengawasan yang dilakukan terhadap absensi karyawan masih belum optimal. Ketiga, mengenai pengendalian batasan sistem aplikasi. Pengendalian batasan sistem aplikasi memiliki beberapa kelemahan sebagai berikut: tidak adanya penggantian password; perusahaan tidak melakukan sistem enkripsi terhadap password user; setiap akses yang dilakukan terhadap sistem tidak direkam, tidak terdapat batasan maksimum untuk kesalahan pemasukan password serta aplikasi tidak menghitung jumlah kehadiran karyawan sehingga kehadiran penghitungan jumlah kehadiran karyawan dihitung secara manual lalu baru diinput ke dalam aplikasi.

Keempat, mengenai pengendalian masukan. Dalam pengendalian masukan masih terdapat kelemahan-kelemahan seperti setiap dokumen yang diinput tidak memiliki nomor urut tercetak; dokumen yang digunakan untuk menentukan besarnya pinjaman tidak mendapat otorisasi dari pihak yang berwenang; tidak membuat berita acara untuk penghancuran dokumen; tidak memiliki alat penghancur kertas untuk penghancuran dokumen; dan sistem penggajian yang tidak dilengkapi dengan help facility; apabila terjadi kesalahan dalam penginputan data, aplikasi tidak menampilkan error message. Kelima, mengenai pengendalian keluaran. Kelemahan-kelemahan yang terdapat pada pengendalian keluaran antara lain: tidak tersedia kolom tanda tangan dan nama pembuat laporan sebagai bukti tanggung jawab atas laporan yang dihasilkan; tidak menggunakan berita acara untuk menghancurkan laporan-laporan yang tidak diperlukan lagi dan perusahaan tidak menggunakan alat penghancur kertas pada proses penghancuran laporan.

\section{DAFTAR PUSTAKA}

Gondodiyoto, S., dan Hendarti, H. (2006). Audit sistem informasi, Jakarta: Mitra Wacana Media.

Gondodiyoto, S. (2003). Audit sistem informasi pendekatan konsep, edisi pertama, Jakarta: PT Media Global Edukasi.

Laudon, K. C., dan Laudon, J. P. (2004). Management information system: managing the digital firm, edisi kedelepan, New Jersey: Prentice Hall.

Mulyadi. (2001). Sistem akuntansi, edisi ketiga, Jakarta: Salemba Empat.

O'Brien, J. A. (2003). Introduction to information system essential for the e-Business enterprise, edisi kesebelas, New York: Mc Graw Hill, Inc.

Rivai, V. (2005). Manajemen sumber daya manusia untuk perusahaan: dari teori ke praktik, edisi pertama, Jakarta: PT Raja Grafindo Persada.

Romney, M. B., and Steinbart, P. J. (2003). Accounting information system, edisi kesembilan, New Jersey: Prentice-Hall, Inc.

Weber, R. (1999). Information system control and audit, New Jersey: Prentice-Hall, Inc.

www.mfgquote.com/resources_web_terms_P.cfm 